\title{
Penerapan Komunikasi Terapeutik dengan Media Flash Card pada Anak yang Mengalami Down Syndrome
}

\author{
Diterima: \\ 10 Januari 2022 \\ Revisi: \\ 13 Januari 2022 \\ Terbit: \\ 14 Februari 2022
}

\author{
${ }^{1 * A m e l l y a ~ A y u ~ P r a m e s t i, ~}{ }^{2}$ Rezki Suci Qamaria \\ 1,2, Psikologi Islam, Institut Agama Islam Negeri (IAIN) Kediri \\ ${ }_{1,2,3}$ Kediri, Indonesia \\ E-mail: ${ }^{1}$ amellyaayupramesti@gmail.com, \\ ${ }^{2}$ rezkisuciqamaria@iainkediri.ac.id
}

*Corresponding Author

\begin{abstract}
Abstrak_-Down Syndrome merupakan kelainan genetik yang mengakibatkan kelainan secara fisik dan mental. Salah satu gangguan perkembangan yang dialami oleh anak yang mengalami Down Syndrome adalah perkembangan berbicara dan berbahasa. Penelitian ini membahas mengenai kondisi salah satu siswa berkebutuhan khusus yaitu anak yang mengalami Down Syndrome di Sekolah Alam X Kota Kediri yang mengalami kesulitan dalam berbicara sehingga komunikasi dalam kesehariannya sangat terbatas. Salah satu langkah untuk mengembangkan perkembangan bicara dan bahasa bagi anak Down Syndrome yaitu dengan terapi wicara. Oleh karena itu, penelitian ini bertujuan untuk membuktikan efektivitas penerapan terapi wicara atau lazimnya disebut komunikasi terapeutik dengan media kartu (flashcard) pada anak Down Syndrome yang memiliki kemampuan berbicara dan berbahasa yang rendah. Adapun teknik-teknik yang digunakan adalah tahap persiapan/pra interaksi, tahap perekenalan/orientasi, tahap kerja, tahap terminasi. Jenis penelitian ini adalah deskriptif kualitatif dengan metode studi kasus, pengumpulan datanya dengan observasi, wawancara mendalam dan dokumentasi serta analisis data secara deskriptif. Hasilnya adalah subjek mendapatkan rasa ingin tahu yang lebih dari sebelumnya dengan adanya media flashcard yang membuat tertarik sehingga terdorong untuk belajar dan kemampuan bicara dan bahasa terus terasah.
\end{abstract}

Kata Kunci- komunikasi, terapeutik, media, flashcard, down syndrome

\begin{abstract}
Down Syndrome is a genetic disorder that causes physical and mental disorders. One of the developmental disorders experienced by children with Down Syndrome is the development of speech and language. This study discusses the condition of one of the students with special needs, namely a child who has Down Syndrome at the Alam X School, Kediri City, who has difficulty speaking so that communication in his daily life is very limited. One of the steps to develop speech and language development for children with Down syndrome is speech therapy. Therefore, this study aims to prove the effectiveness of the application of speech therapy or commonly called therapeutic communication using flashcards in Down Syndrome children who have low speech and language skills. The techniques used are the preparation/preinteraction stage, the introduction/orientation stage, the work stage, and the termination stage. This type of research is descriptive qualitative with case study methods, data collection by observation, in-depth interviews, and documentation as well as descriptive data analysis. The result is that the subject gets more curious than before with the presence of flashcard media that makes them interested so that they are encouraged to learn, and their speaking and language skills continue to be honed.
\end{abstract}

Keywords - communication, therapeutic, media, flashcard, down syndrome 
PTK, Vol.2 No.2 2022

ISSN: 2747-1977 (Print) / 2747-1969 (Online)

DOI: https://doi.org/10.53624/ptk.v2i2.92

\section{PENDAHULUAN}

Kemampuan berbicara amat penting bagi manusia dikarenakan kemampuan berbicara terkait dengan kemampuan berkomunikasi yangmana suatu hal yang wajib dilakukan setiap individu, terutama ketika bersinggungan dengan orang lain. Berbicara ialah suatu keterampilan berbahasa untuk mengungkap ide, gagasan, perasaan secara lisan sebagai proses komunikasi kepada orang lain. Dalam proses ini, seseorang akan mengalami proses berpikir dan di dalam proses berpikir inilah erat kaitannya dengan bahasa, karena individu sanggup membentuk ratusan apalagi ribuan simbol-simbol di dalam otak. Berbicara adalah suatu untuk mengomunikasikan gagasan-gagasan yang disusun serta dikembangkan sesuai dengan kebutuhan-kebutuhan sang pendengar atau penyimak (Liliweri, 2015). Tujuan utama dari berbicara adalah untuk berkomunikasi. Kemampuan berkomunikasi merupakan salah satu tumbuh kembang paling utama bagi anak. Hambatan dalam perkembangan anak dapat terjadi dalam berbagai aspek yang terdiri atas kemampuan kognitif, bahasa, motorik, sosio-emosional, agama dan moral. Menyoal sistem tumbuh kembang anak, maka kebanyakan tak terlepas dari masalah atau halangan dari sistem tersebut. Salah satu kasus atau rintangan yang sering dialami oleh anak-anak yaitu masalah berbicara dan bahasa. Kemampuan berbahasa ditandai dengan bermacam aspek, seperti kekuatan bersuara, tersenyum, berceloteh, berteriak, tertawa, menjerit, menoleh ke arah sumber bunyi, memakai vokalisasi menjadi banyak, mempunyai banyak perbendaharaan kata, mengombinasikan kata-kata, menunjukan lambaian anggota badan, mengenal dan responsif terhadap orang lain dan masih bayak lagi. Masalah komunikasi merupakan indikator awal tahap perkembangan yang sanggup merubah hasil akademik dan sosial bagi anak. Pada anak berkebutuhan khusus dalam proses ini pula terdapat masalah di dalamnya yang kompleks, terhitung di dalamnya yaitu masalah interaksi komunikasi, di mana rintangan selanjutnya yang senantiasa ada di tiap-tiap individu berkebutuhan khusus, terlebih jikalau rintangan yang utama disertai hambatan lain (hambatan majemuk). Hambatan majemuk merupakan suatu kombinasi hambatan baik dua jenis atau lebih yang menyebabkan anak tidak mampu diatasi hanya dengan suatu program pendidikan khusus hanya untuk satu gangguan saja, melainkan perlu didekati dengan variasi program pendidikan sesuai kelainan yang dimiliki. Dalam kajian ini yang dimaksud adalah anak Down Syndrome.

Menurut Center for Biodiversity dan Biotechnology (ICBB), Bogor, angka penyandang Down Syndrome mencapai 8 juta jiwa di dunia, sedangkan di Indonesia sendiri terdapat lebih dari 300.000 manusia Down Syndrome. Selain itu, kira-kira 1 berbanding 700 kelahiran. Data yang diperoleh dalam beberapa kasus, terlihat bahwa umur wanita terbukti berpengaruh besar terhadap munculnya Down Syndrome pada bayi yang dilahirkan (Kemenkes, 2014). Kemungkinan wanita 
berumur 30 tahun melahirkan bayi dengan Down Syndrome adalah 1:1000, sedangkan jika usia kelahiran adalah 35 tahun, kemungkinan adalah 1:400. Hal ini menunjukkan angka kemungkinan munculnya Down Syndrome makin tinggi sesuai usia ibu saat melahirkan. Down Syndrome adalah kelainan yang terjadi pada anak yang mengalami keterbelakangan mental yang disebabkan oleh adanya kelainan pada kromosom nomor 21 yang tidak terdiri dari 2 kromosom sebagaimana mestinya melainkan tiga kromosom yang mengakibatkan anak mengalami (Kosasih, 2012). Anak dengan kondisi Down Syndrome mengalami keterbelakangan secara fisik dan mental, karena Down Syndrome merupakan salah satu penyebab dari retardasi mental, dimana anak-anak yang mengalami keterbelakangan dalam berbahasa berbicara. Keterbelakangan mental ini diakibatkan oleh adanya gangguan pada sistem syaraf pusat dan dalam terapi wicara kondisi ini disebut dengan disleksia. Karakteristik anak Down syndrome salah satunya adalah terbatasnya kemampuan kognitifnya. Kemampuan kognitif yang terbatas maka akan mempengaruhi akademiknya (Jarvis, 2011; Mangunsong, 2011). Anak Down Syndrome biasanya mengalami problem dalam belajar karena kemampuan atensi, metakognisi, kemampuan mengingat, dan generalisasi yang lambat dibandingkan anak lain. Hal ini karena lemahnya dalam mempersepsikan dan menilai, ingatan jangka pendek. Anak Down Syndrome mirip dengan anak lain dimana harus mampu berkomunikasi sejak dini. Tetapi, mereka mempunya beberapa hambatan seperti fisik dan kognitif yang memicu bahasa lisan sulit digunakan dalam komunikasi sehari-hari. Anak-anak dengan Down Syndrome memiliki kesulitan tertentu dalam memproduksi suara dan memahami peraturan kebahasaan sebagai akibat yang muncul dari keterbatasan yang terjadi pada perkembangan bahasa mereka. Komunikasi dengan siswa down syndrome sulit dilakukan, sebagaimana yang telah penulis coba untuk berkomunikasi dengan siswa Down Syndrome di Sekolah Alam X, Kota Kediri. Mereka barangkali mengetahui apa yang orang lain sampaikan tetapi sebagai orang yang baru mengenal siswa Down Syndrome, maka sulit untuk mengerti apa yang dikatakan. Namun hal ini biasa bagi guru yang mengajar di Sekolah Alam X, Kota Kediri. Reformasi ini bisa membuat siswa Down Syndrome meraih prestasi, menjadikan mereka hidup mandiri, serta mengembangkan bakat mereka dengan cara komunikasi guru itu sendiri. Proses komunikasi terapeutik sebenarnya proses yang sangat perlu dilakukan dalam pemulihan pasien dengan keluhan tertentu, perihal ini berlaku untuk anak yang mempunyai masalah dalam faktor perkembangan. Proses ini sudah pasti mempunyai tingkatan yang lebih tinggi, apalagi bagi anak yang mengalami hambatan berkomunikasi atau kemampuan reseptif dan ekspresif. Salah satu solusi penanganannya yaitu dengan melaksanakan terapi wicara dalam bentuk komunikasi terapeutik. Terapi pada anak penyandang Down Syndrome lebih mengacu kepada bagaimana anak dapat hidup dengan kesehatan yang lebih baik dan bagaimana anak dapat bersosialisasi dan hidup dalam masyarakat, agar dapat mandiri dan mengurangi ketergantungan 
PTK, Vol.2 No.2 2022

ISSN: 2747-1977 (Print) / 2747-1969 (Online)

DOI: https://doi.org/10.53624/ptk.v2i2.92

kepada orang lain. Sehingga proses komunikasi yang terjadi menuju kearah yang lebih baik, yang artinya interaksi sosial anak Down Syndrome dengan orang lain terdapat kemajuan. Kemajuan atau peningkatan interaksi sosial yang dimaksud tidak hanya melalui komunikasi secara nonverbal, tetapi juga secara verbal. Selain itu program terapi pada anak penyandang Down Syndrome diharapkan dapat mencegah terjadinya kemunduran kemampuan, baik fisik maupun mental.

Dalam penelitian ini, peneliti pula menggunakan flash card untuk mempermudah penelitian. Kartu kilas (flashcard) adalah kartu kecil yang berisi gambar, teks, atau tanda simbol yang mengingatkan atau menuntun siswa kepada sesuatu yang berhubungan dengan gambar itu, yang biasanya berukuran $8 \times 12 \mathrm{~cm}$, atau dapat disesuaikan dengan besar kecilnya kelas yang dihadapi (Arsyad, 2015). Agar tercipta kegiatan belajar mengajar yang ramah dan menyenangkan serta dapat meningkatkan kosakata, maka peneliti menyampaikan materi menggunakan media kartu bergambar. Gambar ialah media visual nyata, yang telah dikenal dalam masing-masing kegiatan pembelajaran, serta memberi uraian perihal maksud bacaan yang ada di dalamnya. Melalui gambar, guru sanggup menerjemahkan ide-ide dalam wujud yang lebih sesuai bagi siswa Down Syndrome. Melalui media gambar mampu memperlancar pencapaian untuk memahami dan mengingat kata-kata yang ada pada gambar. Media pembelajaran visual memberikan konteks untuk memahami teks, membantu siswa yang lemah dalam membaca untuk meningkatkan kosakata (Rasmitadila, 2017). Penelitian ini melibatkan salah satu siswa yang mengalami Down Syndrome di Sekolah Alam X, Kota Kediri. Sekolah ini merupakan sekolah inklusi dan untuk kalangan menengah ke bawah yang memiliki komitmen memanusiakan manusia, tanpa membedakan anak normal dengan anak berkebutuhan khusus (ABK). Pendidikan inklusi di Sekolah Alam X, Kota Kediri berkiblat pada Ki Hajar Dewantara, dan mengadopsi sistem "Among". Anak normal dan anak berkebutuhan khusus mendapat kasih sayang dan toleransi yang sama. Siswa ABK akan mendapatkan pelayanan pendampingan sesuai kekhususan yang dimilikinya. Oleh karena itu, peneliti tergerak untuk mengkaji penerapan komunikasi terapeutik dengan media flash card pada anak down syndrome sebagai salah satu alternatif penanganan yang mampu menjawab kebutuhan khusus siswa di Sekolah Alam X, Kota Kediri yaitu kebutuhan stimulasi kemampuan berbicara dan berbahasa.

\section{METODE}

Karakteristik dari sasaran penelitian adalah salah satu siswa anak berkebutuhan khusus (ABK) penyandang Down Syndrome. Siswa Down Syndrome yang memiliki dan mengalami hambatan serta keterbelakangan mental yang jauh dari rata-rata (IQ berada dibawah 70). Kondisi tersebut menyebabkan anak kesulitan dalam menyelesaikan tugas-tugas akademik, berkomunikasi, maupun aktivitas sosial. 
Subjek dalam penelitian ini adalah siswa kelas 1 SD yang berusia 7 tahun di Sekolah Alam X, Kota Kediri. Jenis penelitian ini menggunakan pendekatan kualitatif dengan metode deskriptif, penelitian kualitatif ialah peneliti yang menggambarkan suatu kondisi dan situasi yang ada secara kongkrit dari penelitian tersebut. Penelitian ini menggunakan metode kualitatif deskriptif untuk memahami fenomena yang ada dan tengah dialami dari subjek penelitian. Metode ini menyajikan secara langsung pada antara hubungan peneliti dan subjek. Sesuai tujuan dan target peneliti yang berfokus pada uraian di lapangan berkenaan bagaimana penerapan komunikasi terapeutik dengan menggunakan media flashcard dalam mengembangkan kemampuan berbicara anak Down Syndrome. Penelitian menggunakan rencana studi kasus, dimana peneliti mengeksplorasi secara mendalam program, kejadian, proses, aktivitas pada satu atau lebih individu. Dalam suau kasus akan terikat oleh waktu dan kegiatan serta peneliti mengumpulkan informasi secara teliti dengan beraneka prosedur pengumpulan data yang dalam waktu lama (Sugiyono, 2015). Pada penelitian ini, pengumpulan data dilakukan secara natural setting dan lebih banyak pada observasi, wawancara mendalam, dan dokumentasi.

a) Sumber Data Primer

Tabel 1. Data Informan dan Kriteria

\begin{tabular}{|c|c|c|c|}
\hline No. & Informan & Jumlah & Kriteria \\
\hline 1. & $\begin{array}{l}\text { Kepala } \\
\text { Yayasan }\end{array}$ & 1 & $\begin{array}{l}\text { Yang mengetahui sejauh mana guru mampu melaksanakan } \\
\text { pembelajaran anak bekebutuhan khusus dan yang } \\
\text { mendukung kebijakan-kebijakan yang ada di Sekolah } \\
\text { Alam Ramadhani. }\end{array}$ \\
\hline 2. & $\begin{array}{l}\text { Pendamping } \\
\text { ABK }\end{array}$ & 2 & $\begin{array}{l}\text { Yang mengetahui jenis atau kategori dan upaya } \\
\text { menanganinya anak berkebutuhan khusus, serta } \\
\text { mengetahui proses pendampingan pembelajaran terhadap } \\
\text { anak berkebutuhan khusus, }\end{array}$ \\
\hline 3. & $\begin{array}{l}\text { Guru } \\
\text { TK }\end{array}$ & 1 & $\begin{array}{l}\text { Yang mengetahui kebutuhan dan karakteristik siswa dalam } \\
\text { pembelajaran yang terjadi di kelas dan sampai mana } \\
\text { penggunaan media pembelajaran dalam proses belajar } \\
\text { mengajar. }\end{array}$ \\
\hline 4. & $\begin{array}{l}\text { Orang } \\
\text { murid }\end{array}$ & 1 & $\begin{array}{l}\text { Yang mengetahui pembentukan kepribadian \& karakter } \\
\text { anak sedari kecil dan mendidik juga membimbing anak } \\
\text { kearah perubahan secara fisik, kognitif, social. }\end{array}$ \\
\hline
\end{tabular}

*Sumber diolah oleh peneliti

b) Sumber Data Sekunder

Data sekunder merupakan data tambahan untuk memperkuat sumber penelitian sebagai acuan penelitian seperti data profil mengenai subjek F dari salah satu pendamping anak penyandang 
PTK, Vol.2 No.2 2022

ISSN: 2747-1977 (Print) / 2747-1969 (Online)

DOI: https://doi.org/10.53624/ptk.v2i2.92

Down Syndrome, buku "Psikologi dan Pendidikan Pembelajaran Anak Berkebutuhan Khusus", video berbagai macam terapi yang ditangani oleh tenaga ahli, foto, jurnal yang terdapat hubungan dengan penelitian dan catatan lapangan.

Peneliti juga menggunakan beberapa dari teknik pengumpulan data-data diatas yaitu: (1) Observasi menggunakan observasi langsung yaitu peneliti terjun ke lapangan terlibat menggunakan panca indera dan observasi tidak langsung mengamati perilaku subjek dari jauh. Observasi langsung yang dilakukan terkait dengan penelitian yaitu assessment. Observasi pula dilakukan pada informan dengan melihat ekspresi dan sikap saat dilakukan wawancara mendalam. Hal tersebut dimaksudkan untuk mengetahui pemaknaan kejadian terkait pada bentuk perilaku yang ditunjukkan. Behavioral checklist memiliki arti bahwa metode ini dapat memberikan keterangan tentang perilaku yang diobservasi muncul (Herdiansyah, 2011). Berdasarkan penelitian yang dikaji, observasi ini mengamati pola perkembangan fisik, kognitif, dan psikososial anak di lingkungan sekolahnya, terutama dalam hal kemampuan berbicara anak penyandang Down Syndrome. Serta melihat pendamping siswa bekebutuhan khusus dalam menangani anak penyandang Down Syndrome sesuai keahliannya dengan mencatat keadaan dan hal yang mendukung penelitian. (2) Wawancara mendalam (In-Deepth-Interview) merupakan percakapan diantara dua pihak, pemberi pertanyaan dan yang memberi jawaban. Melalui wawancara, peneliti menggali data dan menemukan informasi dari narasumber. Wawancara mendalam (in-deepth-interview) menggunakan instrument pedoman wawancara dengan semiterstruktur yang sifatnya terbuka dan mendalam. Wawancara dilakukan kepada informan yang sudah dipilih melalui teknik purposive sampling. Yaitu teknik pengambilan sampel dengan berbagai pertimbangan-pertimbangan tertentu. Sehingga peneliti dapat menggali dan mendapatkan data yang kaya dari informan. Wawancara direkam menggunakan alat perekam (digital record) untuk memudahkan peneliti mendapatkan seluruh rekaman jawaban dari informan. Wawancara dilakukan kepada 5 informan yaitu Kepala Yayasan, Pendamping anak berkebutuhan khusus (ABK), Guru TK, dan orang tua murid. Wawancara dilakukan dengan face to face menyesuaikan dengan keadaan. (3) Dokumentasi yaitu cara menyatukan dokumen dan data-data yang dibutuhkan, setelah itu ditelaah secara lebih intens dalam rangka meningkatkan keyakinan sekaligus menjadi bukti adanya kejadian. Dokumentasi bisa berupa buku-buku, gambar atau video sebagai sumber dari objek penelitian. Sumber-sumber dokumentasi yang paling penting dari peneliti adalah laporan harian selama penelitian berlangsung dan biodata subjek.

Penelitian ini menggunakan komunikasi terapeutik atau terapi wicara dengan pendekatan flashcard therapist untuk meningkatkan kemampuan berbicara subjek F. Dalam proses komunikasi terapeutik terbagi menjadi empat tahapan yaitu tahap persiapan atau tahap pra- 
interaksi, tahap perkenalan atau orientasi, tahap kerja dan tahap terminasi (Stuart, 2009). Jenis terapi yang digunakan peneliti beragam seperti menggunakan flashcard, puzzle, balok, mobilmobilan, boneka, dan miniatur mainan. Dari beragam alat bantu atau media tersebut yang paling sering digunakan dalam terapi wicara adalah flashcard, karena dengan flashcard therapist mudah menampilkan berbagai macam bentuk dan pola yang disenangi anak-anak dan kosa kata yang tersedia lebih banyak dibandingkan dengan media yang lainnya. Berikut teknik-teknik yang digunakan yaitu: (1) Tahap persiapan/pra interaksi, peneliti sebelumnya mampu mengobservasi sikap subjek dan mencari informasi sebanyak-banyaknya tentang subjek melalui orang tua. Lalu, merancang beberapa strategi yang dapat dilakukan terhadap tiap-tiap pertemuan dengan subjek.

(2) Tahap perkenalan/orientasi, peneliti senantiasa mengulang memperkenalkan dirinya tiapkali sesi terapi wicara yang dijalankan dan upaya validasi keakuratan data dan konsep yang telah dibuat ulang sesuai dengan keadaan subjek, serta mengevaluasi hasil tindakan yang telah lalu. (3) Tahap kerja, proses pelaksanaan komunikasi terapeutik dilakukan proses terapi dengan berbagai metode. Dalam prosesnya metode yang digunakan sesuai dengan usia dan kemampuan subjek. (4) Tahap terminasi, peneliti berupaya membangun kedekatan dan rasa percaya dengan menjalin komunikasi dan saling berkoordinasi dengan pihak sekolah tentang model terapi yang digunakan sebagai tindak lanjut dan setiap perkembangan terapi akan di catat peneliti sebagai bahan tambahan ke dalam program terapi jangka pendek.

\section{HASIL DAN PEMBAHASAN}

\section{A. Paparan Hasil}

Dalam komunikasi terapeutik terdapat beberapa proses dan tahapan yang berkesinambungan di antaranya adalah tahap persiapan/pra interaksi, perkenalan/orientasi, kerja, dan terminasi. Proses ini banyak digunakan komunikasi verbal yang juga diiringi dengan komunikasi non-verbal, dikarenakan komunikasi non-verbal sesungguhnya ditujukan untuk melengkapi dan menegaskan makna dari komunikasi verbal yang dilakukan seseorang. Berikut dipaparkan proses dan tahapannya menggunakan terapi wicara dengan media flashcad pada anak penyandang Down Syndrome :

Tabel 2. Proses dan tahapan menggunakan terapi wicara dengan media flashcad

\section{Tahap Persiapan/Pra Interaksi}

Tahap persiapan atau pra interaksi adalah masa persiapan sebelum berhubungan dan berkomunikasi dengan klien. Pada sesi ini, peneliti mulai menggali kemampuan yang dimiliki sebelum melakukan kontak dengan anak. Peneliti memahami dulu kondisi anak yang akan ditangani termasuk kebiasaan sehari-harinya di Sekolah. Dalam proses ini, observasi awal dengan cara melihat kondisi awal anak, 
PTK, Vol.2 No.2 2022

ISSN: 2747-1977 (Print) / 2747-1969 (Online)

DOI: https://doi.org/10.53624/ptk.v2i2.92

apakah anak tersebut mampu langsung diajak interaksi atau tidak. Alhasil, peneliti kesulitan berinteraksi karena subjek merasa asing dengan orang-orang baru dan menunjukkan perilaku tantrum. Jika subjek menangis, langkah yang dilakukan dengan didiamkan terlebih dahulu agar anak dapat meluapkan emosinya.

\section{Tahap Perkenalan/Orientasi}

Peneliti mulai memperkenalkan diri pada subjek ataupun keluarga. Dalam tahap ini adanya keterbukaan dari subjek agar proses komunikasi terapeutik yang akan dilakukan dapat berjalan dengan lancar. Tahapan ini masih berkaitan dengan tahap pra interaksi. Tujuannya yaitu mampu membangun interaksi seperti berusaha mengajak berkenalan dengan cara mengajak anak untuk berjabat tangan. Subjek terlihat menurut meskipun malu-malu. Bahkan subjek perlahan-lahan mulai memanggil wanita berhijab dengan sebutan "Ustadzah" dan laki-laki (dewasa) bertubuh besar "Bapak" meskipun artikulasinya tidak jelas. Selanjutnya, komunikasi bersama orang tua subjek yang dalam hal ini masuk orientasi stage. Dengan menggali kasus dan problematica pada anak yang menentukan apa yang harus dilakukan selanjutnya. Peneliti akan memantau keadaan anak secara fisik yang lantas dilanjutkan dengan bertanya langsung terhadap orang tuanya mengenai keadaan anak, sekaligus menyusun rencana tindakan. Pertanyaan yang diajukan seperti: kegiatan sehari-hari anak di rumah, interaksi sosial di lingkungan keluarga maupun masyarakat, pola makan dan pantangannya, gambaran pola asuh orang tua yang berpengaruh terhadap kemandirian anak.

Hal ini dikarenakan orang tua yang mengerti tentang kondisi anak. Selanjutnya, peneliti akan tetap menyesuaikan dengan perilaku anak terlebih dahulu. Maksudnya, tidak langsung melakukan proses terapi. Jadi pada tahap ini, hampir sama mekanismenya dengan tahap pra interaksi. Peneliti mampu menyesuaikan diri dan lingkungan dengan kondisi anak. Dalam hal ini pula, peneliti berhasil membangun kelekatan atau keakraban dengan anak melalui kegiatan yang disukai seperti bermain mainan kereta api, mengajak anak mengenal gambar-gambar di buku, bermain puzzle tikar, memainkan angklung, mengenal nama-nama hewan di poster "nama-nama hewan peliharaan" sehingga memudahkan untuk dimulainya terapi.

\section{Tahap Kerja}

Pada tahap ini peneliti melakukan active listening untuk menyelesaikan masalah. Melalui active listening, peneliti mendefinisikan masalah, bagaimana cara mengatasinya dan mengevaluasi cara pemecahan masalah yang telah dipilih. Peneliti menggunakan visualisasi media flashcard yang mempermudah anak dalam memahami suatu hal dan lebih bisa mempengaruhi emosi anak secara signifikan. Teknik komunikasi terapeutik yang sering digunakan pada tahap ini antara lain:

a. Eksplorasi untuk memastikan kemampuan fisik dan mental subjek

Peneliti mampu menaksirkan mood subjek saat tiba di sekolah. Jika kondisi subjek kurang baik hingga perilaku tantrum, maka terapi tidak dilakukan pada hari tersebut. Namun peneliti tetap membujuk subjek melakukan permainan yang disukai untuk mengurangi luapan emosi agar tidak 
terjadi kekacauan di kelas. Berdasarkan uraian aktivitas yang subjek sukai pada tahap orientasi, subjek menyukai hal-hal yang membuat ia menarik dan biasanya sudah dilakukan di sekolah secara berulang. Subjek tidak pernah merasa bosan.

b. Refleksi. Peneliti dan pendamping khusus mendiskusikan hasil yang meliputi kelebihan dan kekurangan pada pembelajaran anak Down Syndrome. Hasil refleksi ini akan digunakan sebagai perbaikan dalam pelaksanaan tahap berikutnya.

c. Berbagi persepsi. Namun, hasil yang didapat subjek masih belum memahami proses terjadinya persepsi dalam komunikasi interpersonal bahkan seringkali terjadi rejection dlam percakapan.

d. Memfokuskan dan menyimpulkan. Untuk meningkatkan kemampuan berbicara subjek yang tentunya lebih mengarah pada proses perbaikan menuju keadaan yang lebih baik. Sesuai tujuan penelitian yang dikaji yaitu untuk meningkatkan kemampuan berbicara anak.

Peneliti mulai melakukan terapi wicara dengan media kartu bergambar/flashcard: nama-nama buah dan sayur, hewan peliharaan, kendaraan, aktivitas sehari-hari di rumah maupun di sekolah. Hal ini bertujuan agar subjek mampu mengkoordinasikan antara kemampuan kognitif dan bahasa, seperti memahami hal yang sudah dipelajari dari media flashcard. Dan mampu mengucapkan kata dengan artikulasi yang jelas. Subjek mulai tertarik dengan gambar yang muncul dan mengenali hal yang ditunjukkan. Subjek terlihat semangat dan muncul rasa ingin tahu berlebih, namun setelah \pm 5 hari, subjek merasa bosan. Sehingga peneliti merancang strategi/metode lain seperti mengajak anak jalan-jalan di area sekolah, melihat hewan peliharaan kelinci, kura-kura di sekolah, sambil menyebutkan hal-hal disekitar dengan lantang agar subjek menirukan apa yang diucapkan peneliti. Subjek pun merespon namun bila peneliti mengucapkan 3-4 suku kata, subjek hanya bisa menirukan suku kata akhir, misal: "ke-lin-ci" menjadi “...nnci” \& bila dengan 2 suku kata, subjek mampu mengucapkan cukup sempurna, misal "sapi" menjadi “...api", "buku” menjadi “...uku”.

\section{Tahap Terminasi}

Pada program terapi wicara pada anak umumnya peneliti melakukan penutupan seperti cara mengucapkan ucapan terima kasih dan salam. Serta mengajarkan tata krama apabila melakukan perpisahan bersama cara cium tangan. Jika subjek masih ingin bermain, maka sebisa mungkin permainannya harus disingkirkan sehingga anak mengerti bahwa jam sekolah sudah usai. Hal yang mengesankan bagi subjek selama proses therapy pada tahap kerja adalah ketika subjek terlihat antusias dengan hal-hal baru dan lebih menyukai ditemani orang dewasa dibandingkan kawan sebaya.

\section{B. Pembahasan}

Hasil yang didapat dari penelitian ini yaitu subjek mengalami perkembangan setelah diberi terapi wicara. Subyek yang semula kurang ekspresif, kurang bisa mengulang kata-kata yang 
PTK, Vol.2 No.2 2022

ISSN: 2747-1977 (Print) / 2747-1969 (Online)

DOI: https://doi.org/10.53624/ptk.v2i2.92

diucapkan orang lain, kurang bisa mengenal nama-nama benda disekitarnya setelah diberi terapi wicara mengalami peningkatan, subyek lebih ekspersif, merespon ucapan orang lain, perbendaharaan kata lebih banyak, dapat mengenal nama-nama benda yang ada disekitarnya. Sehingga, peneliti sepakat menggunakan terapi wicara berbasis kartu bergambar (flashcard) karena strategi ini efektif untuk meningkatkan kemampuan komunikasi anak yang mengalami Down Syndrome.

Hasil tersebt juga senada dengan hasil penelitian yang dilakukan oleh Inggrida dalam penelitiannya yang berjudul "Penggunaan Media Flash Card terhadap Kemampuan Kognitif Mengenal Konsep Bilangan 1-10 di Kelompok A TK Islam Insan Al-Firdaus" yang menggunakan pendekatan kuantitatif dengan jenis pre-eksperimental design berbentuk one-group pretestposttest design pada 20 anak kelompok A juga memperoleh hasil penelitian yang menunjukkan bahwa flash card memiliki pengaruh yang signifikan terhadap kemampuan kognitif anak kelompok A, salah satunya pada kemampuan berbicara dan berbahasa (Inggrida, 2014). Penggunaan media flash card sesungguhnya memiliki fungsi utama, yaitu berfungsi menstimulasi perkembangan kognitif, sosial, bicara, bahasa, dan emosi pada anak (Kurniawan, 2020).

\section{KESIMPULAN}

Penerapan komunikasi terapeutik dengan menggunakan media flashcard sangat bermanfaat dalam mengembangkan kemampuan berbicara dan berbahasa pada anak yang menglami Down Syndrome. Penggunaan flashcard therapist membantu guru/pendamping menampilkan berbagai macam bentuk dan pola yang disenangi anak-anak dan kosa kata yang tersedia lebih banyak dibandingkan dengan media-media lainnya. Pembelajaran dengan menggunakan media pembelajaran flashcard juga dapat meningkatkan hasil belajar di sekolah maupun di rumah. Komunikasi terapeutik berbasis kartu (flash card) ini efektif digunakan bagi anak yang memiliki kemampuan berbicara atau berbahasa yang rendah, namun karena perbedaan karakter dan nilai anak pada masing-masing individu dalam mempersepsikan metode yang telah dipakai dan perkembangan kognisi, bahasa, sosio-emosional yang berbeda pula.

\section{DAFTAR PUSTAKA}

Arsyad, Azhar. (2015). Media Pembelajaran. Jakarta: PT Raja Grafindo Persada.

E., Kosasih. (2012). Cara Bijak Memahami Anak Berkebutuhan Khusus. Bandung: Yrama Widya. Herdiansyah, Haris. (2011). Metodologi Penelitian Kualitatif untuk Ilmu-Ilmu Sosial. Salemba Humanika: Jakarta.

Inggrida, P. C. (2014). Penggunaan Media Flashcard Terhadap Perkembangan Berpikir Kognitif Mengenal Konsep Bilangan 1-10 Di Kelompok A TK Islam Insan Al-Firdaus. Jurnal Mahasiswa UNESA, 3-4.

Kemenkes Kesehatan RI. (2014). Situasi Penyandang Disabilitas. Jakarta: Kementrian Kesehatan RI. 
ISSN: 2747-1977 (Print) / 2747-1969 (Online)

DOI: https://doi.org/10.53624/ptk.v2i2.92

Kurniawan, Marwany, \& Laely. (2020). Bermain dan Permainan Anak Usia Dini”. Bandung: Remaja Rosdakarya.

Liliweri, A. (2015). Komunikasi Antarpersonal. Jakarta: Kencana Medika.

Mangunsong, Frieda. (2011). Psikologi dan Pendidikan Anak Berkebutuhan Khusus, jilid kedua. Jakarta: Penerbit LPSP3 UI.

Matt Jarvis. (2011). Teori-teori Psikologi, Cetakan ke X. Bandung: Nusa Media.

Rasmitadila, R., \& Goldstein, B. (2017). The Role of Special Assistant Teacher to Help Special Needs Student through Instructional Interactions in an Inclusive Classroom. International Journal of Special Education. 32 (3) pp 499-500.

Sugiyono. (2015). Metode Penelitian Kuantitatif, Kualitatif dan R\&D. Bandung: PT Alfabet. 